\title{
AN INTEGRATED AQUAPONIC SYSTEM FOR FISH POND WATER TREATMENT TO PRODUCE BARLEY CROP
}

\author{
Mahenor A. Ebrahim', M. M. Hegazi², \\ K. F. Al-Bagoury ${ }^{3}$ and H. A. Farag ${ }^{4}$
}

\begin{abstract}
The experiment was started at the spring of 2013 located in Giza governorate by installing an integrated aquaponic system for purification wastewater from fish pond and production of a forge crop. The effects of seeding quantity, water time duration on crop yield and pollutions reduction were studied in this study. The results indicated that Barley forge crop could be produced in 23days from germination to harvest. The treatment $2.5 \mathrm{~kg} / \mathrm{m}^{2}$ seed quantity with 5 days water time of duration gaves the best result for vegetative yield $\left(17.23 \mathrm{~kg} / \mathrm{m}^{2}\right)$. Based on sixteen harvests per year, a total possible yield of $275.68 \mathrm{~kg} / \mathrm{m}^{2}$. This is more than 367.5 time greater than the yield obtainable from filed grown conventional forge of $0.75 \mathrm{~kg} / \mathrm{m}^{2}$. The pollution reduction range from $20-46.51 \%, 12.28-45.06 \%, 52.69-73.5 \%, 61.13-90.53 \%$ and $2.43-4.41$ $\%$ can be achieved for the chemical oxygen demand (COD), total solids (TS), nitrate - nitrogen $\left(\mathrm{NO}_{3}{ }^{-} \mathrm{N}\right)$, phosphate - phosphorus $\left(\mathrm{PO}_{4}{ }^{3-}-\mathrm{P}\right)$ and potassium oxide $\left(\mathrm{K}_{2} \mathrm{O}\right)$, respectively.
\end{abstract}

\section{INTRODUCTION}

quaponic is an integrated system to cultivate fish with plant.
The fish waste used as the nutrient solution for the hydroponic
plants and the plants helps to clean the water to reuse it in the fish tank. Fish production of capture in Egypt is 385000 tons in 2010 (264000 tons for inland and 121000 tons for marine) and 920000 tons for inland aquaculture (FAO, 2013).

1- Researcher Assistant in Agricultural Engineering Research Institute.

2- Prof. Emt. of Agric. Eng., Dept. of Agric. Eng., Fac. Agric., Ain Shams Univ.

3- Assoc. Prof. of Agric. Eng., Dept. of Agric. Eng., Fac. Agric., Ain Shams Univ.

4- Senior Researcher in Agricultural Engineering Research Institute. Agricultural Research Center. 
Adler et al. (2003) mentioned to hydroponic plants have been widely used in wastewater treatment systems because they can efficiently absorb dissolved compounds in the wastewater as nutrients for plant growth.

Abo-haded et al. (2006) said that plants use as biofilter to fish where the absorption of ammonia resulting from fish waste and convert them into compounds suitable for dynamic interactions within and used in building tissues.

Gegner (2006) explained that both open and closed systems can be adapted to a wide range of species and situations. Tanks made of steel, fiberglass, or plastic can be dismantled and reassembled for transporting or relocating. Advantages of tank culture include minimal land requirements, portability, and ease of expansion. Tanks can be located indoors to reduce climate limitations. High equipment cost, especially in closed systems, is the main disadvantage of tank culture.

Ghaly and Farag (2007) defined that Phytoremediation is a low tech, low cost emerging clean up technology for wastewaters. It is defined as the engineered use of green plants to remove, or render harmless, various environmental contaminates such as inorganic and organic compounds. This definition includes all plant influenced biological, chemical and physical processes that aid in the uptake and degradation of contaminates by plants.

DeLong et al. (2009) said that Nitrate $\left(\mathrm{NO}_{3}{ }^{-}\right)$toxicity can occur if levels in water reuse systems exceed the 300 to $400 \mathrm{mg} / \mathrm{L}$ nitrate-nitrogen range. Normal water exchanges during filter backwashing or solids removal generally control nitrate concentrations. Water exchange or a denitrification process may be required.

Sorenson and Relf (2009) explained that whether a plant is grown in soil or a soilless medium, there are many factors affecting plant growth and productivity. All plants require nutrients, water, light, and air to grow. A plant grows in soil obtains nutrients and water from the soil, when available. With hydroponics, because water and nutrients are always available, the plant is never stressed. Sunlight and air are readily available in an outdoor hydroponic system. 
Bhatnagar (2013) mentioned to the optimum fish production is totally dependent on the physical, chemical and biological qualities of water to most of the extent. Hence, successful pond management requires an understanding of water quality. Water quality is determined by variables like temperature, transparency, turbidity, water colour, carbon dioxide, $\mathrm{pH}$, alkalinity, hardness, unionised ammonia, nitrite, nitrate, primary productivity, BOD, plankton population etc.

Murray et al. (2014) said that Recirculating Aquaculture Systems (RAS) are intensive, usually indoor tank-based systems that achieve high rates of water re-use by mechanical, biological chemical filtration and other treatment steps. Precise environmental control means aquatic species can be cultured out with their normal climatic range, allowing operators to prioritise production goals linked to market, regulatory or resource availability criteria

The objectives of this study are:

- Constructed an integrated system combined with fish and forge crop production.

- Possibility of using plants for purification of the fish ponds wastewater, to assess the ability of hydroponically produced and reduces the pollution potential of the waste water and reuses it to the fish ponds.

- Determine the influent of wastewater that must be supplied to plant.

\section{MATERIAL AND METHODS}

The experiment was started in the spring (April) 2013 located in Giza governorate by setup and constructed the system and test it. The aquaponic system was used in this study consists of the following: parts (Fig. 1).

2.1. Aquaculture system: The Aquaculture unites consists of fish tank and aeration system, while Nile Tilapia fish varity was culture by density was 100 fish $(10 \mathrm{~g}) / \mathrm{m}^{3}$.

Fish tank dimensions from the top are $(123 * 123 \mathrm{~cm})$ and the bottom is $(106.5 * 106.5 \mathrm{~cm})$ and $122 \mathrm{~cm}$ height. It's made from fiber glass. 
The aeration system is used to provide the needing Oxygen to the fish using two air pump (3.5L/min discharge).

The Aquaculture unites was supported by warming system and shaded unit to adjust the temperature inside the fish pond to be $28^{\circ} \mathrm{C}$ which is the optimum Tilapia fish temperature growth (DeLong et al. 2009).

2.2. Hydroponic unites: The hydroponic unites consists of frame, growth throughs, aeration system and waste application. The frame was constructed from wood $(100 \mathrm{~cm}$ width and $200 \mathrm{~cm}$ length).The frame divided into two rows; each row is divided into four parts. Each part was placed by tray as a growth throughs.

Eight trays used, they were made from Galvanized steel sheet which acted as plant support medium with a wire-mesh $\left(16 \mathrm{hols} / \mathrm{cm}^{2}\right)$ placed in every tray. The tray dimensions of $(50 * 40 \mathrm{~cm})$ and the wire mesh dimensions of $45 * 35 \mathrm{~cm}$. and every tray have four supports $5 \mathrm{~cm}$ height.

Water application, which the water coming out from the hydroponic system collected and then storage in a cylinder tank $42 \mathrm{~cm}$ diameter from top and bottom , $49 \mathrm{~cm}$ at the middle and $90 \mathrm{~cm}$ height. The waste water storage tank was connected to a pump using PVC tube 1/2" to transfer the water from the storage tank to Aquaculture system (fish pond), the pump powered by motor $1 / 2 \mathrm{hp}$ and $31 \mathrm{~m}^{3} / \mathrm{hr}$ and $21 \mathrm{~m}$ head.

At the top of the cylindrical tank were 8 fitting T-shape mounted which are using to collect samples for analysis and collected the water which out from the hydroponic system and allow it to enter into the fish pond if it is totally filtrated.

The influent waste water from fish pond analyses to determine the nutrients quantity includes $(\mathrm{N}, \mathrm{P}$, and $\mathrm{K})$. The nutrients in wastewater need to the plants as sufficient fertilizer or may be need to add chemical nutrients.

Barley (Hordeum Vulgre) was used in the study as the forge crop. It is currently popular in temperate areas where it is grown as a summer crop and tropical areas where it is sown as a winter crop. Barley grows under semi cooled conditions but is not particularly winter hardy, it has been 
successfully grown in a hydroponic system. The nutrient uptake capacity is $15 \mathrm{~kg} \mathrm{P}_{2} \mathrm{O}_{5} / \mathrm{fed}, 45 \mathrm{~kg} \mathrm{~N} / \mathrm{fed}$ and $24 \mathrm{~kg} \mathrm{~K}_{2} \mathrm{O} / \mathrm{fed}$. And the average yield $(960-1080 \mathrm{~kg}$ seed, $750-1000 \mathrm{~kg}$ straw / fed, and 3000kg selage/fed).

The experiment was study the effect of two seed quantity $(300 \mathrm{~g}$ and $500 \mathrm{~g}$ was required to cover the surface of tray) and 3,5days water time duration.

The Nitrite was measured using Ammonia instruments every day to guard the Nitrite in $0.1 \mathrm{mg} / \mathrm{L}$

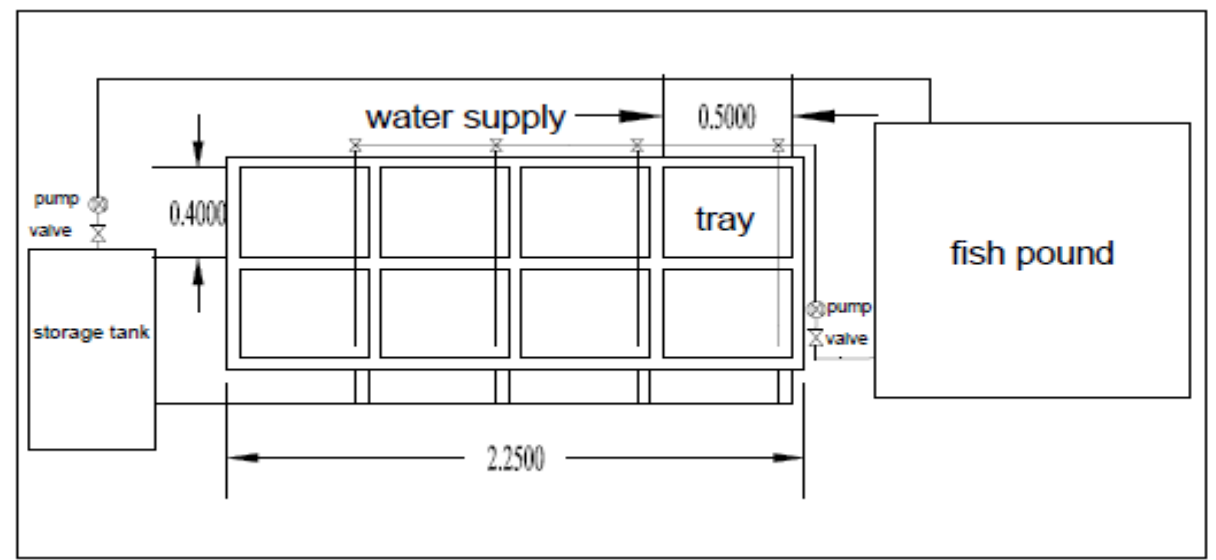

Fig. 1: Show the Aquaculture and hydroponic system (dimensions in $\mathrm{m}$ ).

\subsection{Wast water supplied quantity:}

Depending on the plants nutrient needs such as N, P and $\mathrm{K}$ the waste water that must be supplied or the duration of water standing in the growth through was determined using the following equation:

$$
\mathrm{N}=\mathrm{N}_{\text {up }} * \mathrm{~A} \quad(\text { Snow, 2007) }
$$

Where $\mathrm{N}, \mathrm{N}_{\text {up }}$ and $\mathrm{A}$ is Nitrogen, Nitrogen Barley uptake and area respectively.

The quantity of waste water needed depended basically of the Nitrogen indeed to the plants that due to we produce a vegetative crop. The total cultivate time was 21 to 23 days that is the optimum duration to produce a good maturity to use as a forage crop (Ghaly and Farag 2007).

The determined of dry mater content was done using the (A.OA.C. 1990) precaduace. 


\section{RESULTS AND DISCUSSIONS:}

\subsection{The waste water characteristics:}

\subsubsection{Influent characterize}

Waste water during fish growth period was analysis before every time change water to enter the hydroponic system as shown in Table 1. The chemical analysis of influent wastewater found to be changeable depended on both of add feed to fish and fish growth.

Table 1: Waste water analysis:

\begin{tabular}{|c|l|l|l|l|l|}
\hline \multirow{2}{*}{ Days after germination } & \multicolumn{5}{|c|}{ Influent analysis (mg/L) } \\
\cline { 2 - 6 } & COD & TS & N & P & K \\
\hline 8 & 115 & 231 & 9.3 & 2.1 & 90.7 \\
\hline 11 & 116 & 250 & 9.3 & 1.4 & 83 \\
\hline 13 & 119 & 300 & 10.7 & 1.1 & 80.4 \\
\hline 14 & 121 & 300 & 10.9 & 1.3 & 106.9 \\
\hline 17 & 123 & 370 & 11.2 & 1.6 & 100.5 \\
\hline 18 & 129 & 375 & 11.7 & 1.6 & 104.2 \\
\hline 20 & 133 & 450 & 12.3 & 2 & 98.8 \\
\hline
\end{tabular}

COD: Chemical oxygen demand

TS: Total solids

$\mathrm{N}$ : Nitrate - Nitrogen $\left(\mathrm{NO}_{3}{ }^{-}-\mathrm{N}\right)$

$\mathrm{P}$ : Phosphate - phosphorus $\left(\mathrm{PO}_{4}{ }^{3-}-\mathrm{P}\right)$

$\mathrm{K}$ : Potassium oxide $\left(\mathrm{K}_{2} \mathrm{O}\right)$

- Calculate the quantity of wastewater that must be supplied to plant.

The number of days required for barley maturate is 120 days and the rate of necessary Nutrient uptake by barley such as N, P, K considered to be constant (Snow, 2007).

\section{1- Nitrogen:-}

Barley uptake $45 \mathrm{~kg} / \mathrm{fed}$ of Nitrogen and The theoretical uptake per day calculated using equation (2-1).

$$
=\frac{45 \mathrm{~kg}}{\mathrm{fed}} \times \frac{1}{120 \text { days }}=\frac{0.375 \mathrm{~kg}}{\mathrm{fed} \cdot \text { day }}
$$

The area of each trough is

$$
A=0.50 \times 0.40=0.2 m^{2}
$$


The required amount of Nitrogen per trough according to the previous equation found to be $0.01875 \mathrm{~g}-\mathrm{N} /$ through.day $(18 \mathrm{mg} /$ through.day)

Since wastewater contains $9.3 \mathrm{mg} / \mathrm{L}$ the theoretical quantity of the wastewater should be supplied

$$
=\frac{0.01875 \text { gof } N}{\text { trough } \cdot \text { day }} \times \frac{1000 m g}{1 g} \times \frac{1 L}{9.3 m g-N}=\frac{2 L}{\text { trough } \cdot \text { day }}
$$

\subsubsection{Effluent characterize}

The reduction in pollution potential was measured by the total solids (TS), chemical oxygen demand $\mathrm{COD}$, Nitrate - Nitrogen $\left(\mathrm{NO}_{3}{ }^{-} \mathrm{N}\right)$, Phosphate - phosphorus $\left(\mathrm{PO}_{4}{ }^{3-}-\mathrm{P}\right)$ and Potassium oxide $\left(\mathrm{K}_{2} \mathrm{O}\right)$ concentration.

Beside to the daily determined of Nitrite on fish pond waste water to keep it always less than $0.1 \mathrm{mg} / \mathrm{L}$ the flowing element were determined in both influent and effluent.

Every time change water, the wastewater (influent) analysis before enters hydroponic system every 3 and 5 days $\left(\mathrm{A}_{1}, \mathrm{~A} 2\right)$ and the effluent which comes from hydroponic system was analysis every changeable period which are 3 days and 5 days $\left(\mathrm{B}_{1}, \mathrm{~B}_{2}\right)$ as following:

\subsubsection{Chemical Oxygen Demand:}

Tables 2 and 3 shown change in effluent chemical oxygen demand (COD) concentration during the growth period from 8 day to 23 day, the COD decreased during the growth period that may be occur because of the crop root system was fully developed and the root filtration capacity of suspended solids and absorption of dissolved nutrients increased with increasing time duration.

Table 2: Change in effluent chemical oxygen demand (COD) concentration for water time duration (3days).

\begin{tabular}{|c|c|c|c|c|c|c|c|c|c|c|c|}
\hline \multirow{2}{*}{$\begin{array}{c}\text { Seed } \\
\text { quantity } \\
\left(\mathrm{kg} / \mathrm{m}^{2}\right)\end{array}$} & \multicolumn{7}{|c|}{ Chemical oxygen demand $(\mathrm{COD}) \mathrm{mg} / \mathrm{L}$} & $\begin{array}{c}\text { Average } \\
\text { decreased } \\
\mathrm{mg} / \mathrm{L}\end{array}$ \\
\hline 1.5 & 115 & 108 & 116 & 98 & 121 & 96 & 123 & 93 & 133 & 90 & 24.6 \\
\hline 2.5 & 115 & 103 & 116 & 89 & 121 & 87 & 123 & 79 & 133 & 81 & 33.8 \\
\hline
\end{tabular}

$\mathrm{A}_{1}$ : Influent application every 3 days

$\mathrm{B}_{1}$ : Effluent application every 3 days

Average decreased $=\sum\left(a_{i}-b_{L}\right) / n$ 
Table 3: Change in effluent chemical oxygen demand (COD) concentration for water time duration (5days).

\begin{tabular}{|c|c|c|c|c|c|c|c|}
\hline \multirow{2}{*}{$\begin{array}{c}\text { Seed quantity } \\
\left(\mathrm{kg} / \mathrm{m}^{2}\right)\end{array}$} & \multicolumn{6}{|c|}{ Chemical oxygen demand (COD) mg/L } & \multirow{2}{*}{$\begin{array}{c}\text { Average } \\
\text { Decreased } \\
\mathrm{mg} / \mathrm{L}\end{array}$} \\
\cline { 2 - 7 } & $\mathrm{A}_{2}$ & $\mathrm{~B}_{2}$ & $\mathrm{~A}_{2}$ & $\mathrm{~B}_{2}$ & $\mathrm{~A}_{2}$ & $\mathrm{~B}_{2}$ & \\
\hline 1.5 & 115 & 100 & 119 & 85 & 129 & 82 & 32 \\
\hline 2.5 & 115 & 92 & 119 & 73 & 129 & 69 & 43 \\
\hline
\end{tabular}

$\mathrm{A}_{2}$ : Influent application every 5 days

$\mathrm{B}_{2}$ : Effluent application every 5 days

The results are presented in Table 2 and 3 shown the change in chemical oxygen demand (COD) concentration in influent and effluent after two time duration (3-5 days) static in hydroponic system. From results, it could be absolved that chemical oxygen demand concentration decreased by average 24.6 and $33.8 \mathrm{mg} / \mathrm{L}$ for $1.5 \mathrm{~kg} / \mathrm{m}^{2}$ and $2.5 \mathrm{~kg} / \mathrm{m}^{2}$ seed quantity with time duration of three days, while 32 and $43 \mathrm{mg} / \mathrm{L}$ for $1.5 \mathrm{~kg} / \mathrm{m}^{2}$ and $2.5 \mathrm{~kg} / \mathrm{m}^{2}$ seed quantity with 5 days.

\subsubsection{Total Solids:}

Tables 4 and 5 show the changes in effluent total solids (TS) which include both of total dissolved solid and total suspended solid, The TS concentration during the growth period from day of 8 to day of 23 increased with increasing time duration and seed quantity.

Table 4: Changes in effluent total solids (TS) concentration for water time duration (3days).

\begin{tabular}{|c|c|c|c|c|c|c|c|c|c|c|c|}
\hline \multirow{2}{*}{$\begin{array}{c}\text { Seed } \\
\text { quantity } \\
\left(\mathrm{kg} / \mathrm{m}^{2}\right)\end{array}$} & \multicolumn{10}{|c|}{ Total solids (TS) mg/L } & \multirow{2}{*}{$\begin{array}{c}\text { Average } \\
\text { decreased } \\
\mathrm{mg} / \mathrm{L}\end{array}$} \\
\hline & $\mathrm{A}_{1}$ & $\mathrm{~B}_{1}$ & $\mathrm{~A}_{1}$ & $\mathrm{~B}_{1}$ & $\mathrm{~A}_{1}$ & $\mathrm{~B}_{1}$ & $\mathrm{~A}_{1}$ & $\mathrm{~B}_{1}$ & $\mathrm{~A}_{1}$ & $\mathrm{~B}_{1}$ & \\
\hline 1.5 & 231 & 227 & 250 & 230 & 300 & 225 & 370 & 263 & 450 & 304 & 70.4 \\
\hline 2.5 & 231 & 218 & 250 & 222 & 300 & 198 & 370 & 239 & 450 & 274 & 89.8 \\
\hline
\end{tabular}


Table 5: Changes in effluent total solids (TS) concentration for water time duration (5days)

\begin{tabular}{|c|c|c|c|c|c|c|c|}
\hline \multirow{2}{*}{$\begin{array}{c}\text { Seed quantity } \\
\left(\mathrm{kg} / \mathrm{m}^{2}\right)\end{array}$} & \multicolumn{6}{|c|}{ Total solids (TS) mg/L } & $\begin{array}{c}\text { Average } \\
\text { Decreased } \\
\mathrm{mg} / \mathrm{L}\end{array}$ \\
\cline { 2 - 7 } & $\mathrm{A}_{2}$ & $\mathrm{~B}_{2}$ & $\mathrm{~A}_{2}$ & $\mathrm{~B}_{2}$ & $\mathrm{~A}_{2}$ & $\mathrm{~B}_{2}$ & \\
\hline 1.5 & 231 & 211 & 300 & 213 & 375 & 231 & 83.7 \\
\hline 2.5 & 231 & 198 & 300 & 177 & 375 & 206 & 108.3 \\
\hline
\end{tabular}

The results in tables 4 and 5 indicated that the total solids (TS) concentration in influent and effluent after two time duration (3-5 days) static in hydroponic system. From results it could be absorved that total solids (TS) concentration decreased by average 70.4 and $89.8 \mathrm{mg} / \mathrm{L}$ for $1.5 \mathrm{~kg} / \mathrm{m}^{2}$ and $2.5 \mathrm{~kg} / \mathrm{m}^{2}$ seed quantity with time duration of three days, while 83.7 and $108.3 \mathrm{mg} / \mathrm{L}$ for $1.5 \mathrm{~kg} / \mathrm{m}^{2}$ and $2.5 \mathrm{~kg} / \mathrm{m}^{2}$ seed quantity with 5days.

\subsubsection{Nitrate-Nitrogen:}

The changes of the effluent shows in Tables 6 and 7 Nitrate - Nitrogen $\left(\mathrm{NO}_{3}{ }^{-} \mathrm{N}\right)$ concentration during the growth period. The effluent $\mathrm{NO}_{3}{ }^{-} \mathrm{N}$ concentration found to be independent on water time duration, it was decreased with increasing time duration.

Table 6: Changes in effluent Nitrate - Nitrogen $\left(\mathrm{NO}_{3}{ }^{-}-\mathrm{N}\right)$ concentration for water time duration (3days).

\begin{tabular}{|c|c|c|c|c|c|c|c|c|c|c|c|}
\hline \multirow{2}{*}{$\begin{array}{l}\text { Seed } \\
\text { quantity } \\
\left(\mathrm{kg} / \mathrm{m}^{2}\right)\end{array}$} & \multicolumn{10}{|c|}{ Nitrate - Nitrogen $\left(\mathrm{NO}_{3}{ }^{-} \mathrm{N}\right) \mathrm{mg} / \mathrm{L}$} & \multirow{2}{*}{$\begin{array}{c}\text { Average } \\
\text { decreased } \\
\mathrm{mg} / \mathrm{L}\end{array}$} \\
\hline & $\mathrm{A}_{1}$ & $\mathrm{~B}_{1}$ & $\mathrm{~A}_{1}$ & $\mathrm{~B}_{1}$ & $\mathrm{~A}_{1}$ & $\mathrm{~B}_{1}$ & $A_{1}$ & $\mathrm{~B}_{1}$ & $\mathrm{~A}_{1}$ & $\mathrm{~B}_{1}$ & \\
\hline 1.5 & 9.3 & 6.3 & 9.3 & 5.4 & 10.9 & 4.8 & 11.2 & 4.9 & 12.3 & 5.2 & 5.28 \\
\hline 2.5 & 9.3 & 5.6 & 9.3 & 4.9 & 10.9 & 4.2 & 11.2 & 4 & 12.3 & 4.2 & 6.02 \\
\hline
\end{tabular}

Table 7: changes in effluent Nitrate - Nitrogen $\left(\mathrm{NO}_{3}{ }^{-} \mathrm{N}\right)$ concentration for water time duration (5days)

\begin{tabular}{|c|c|c|c|c|c|c|c|}
\hline \multirow{2}{*}{$\begin{array}{c}\text { Seed quantity } \\
\left(\mathrm{kg} / \mathrm{m}^{2}\right)\end{array}$} & \multicolumn{6}{|c|}{ Nitrate - Nitrogen $\left(\mathrm{NO}_{3}{ }^{-}-\mathrm{N}\right) \mathrm{mg} / \mathrm{L}$} & $\begin{array}{c}\text { Average } \\
\text { Decreased } \\
\mathrm{mg} / \mathrm{L}\end{array}$ \\
\cline { 2 - 7 } & $\mathrm{A}_{2}$ & $\mathrm{~B}_{2}$ & $\mathrm{~A}_{2}$ & $\mathrm{~B}_{2}$ & $\mathrm{~A}_{2}$ & $\mathrm{~B}_{2}$ & \\
\hline 1.5 & 9.3 & 5.4 & 10.7 & 4.2 & 11.7 & 4.1 & 6 \\
\hline 2.5 & 9.3 & 4.4 & 10.7 & 3 & 11.7 & 3.1 & 7.07 \\
\hline
\end{tabular}


The result indicated in table 6 and 7 shown the Nitrate - Nitrogen $\left(\mathrm{NO}_{3}{ }^{-}-\right.$ $\mathrm{N})$ concentration in influent and effluent after two time duration (3-5 days) static in hydroponic system. From these results it could be absorved that Nitrate - Nitrogen $\left(\mathrm{NO}_{3}{ }^{-} \mathrm{N}\right)$ concentration decreased by average 5.28 and 6.02 for $1.5 \mathrm{~kg} / \mathrm{m}^{2}$ and $2.5 \mathrm{~kg} / \mathrm{m}^{2}$ with time duration of three days, while 6 and 7.07 for $1.5 \mathrm{~kg} / \mathrm{m}^{2}$ and $2.5 \mathrm{~kg} / \mathrm{m}^{2}$ with 5 days.

\subsubsection{Phosphate - Phosphorus:}

Tables 8 and 9 show the analysis result in effluent Phosphate phosphorus $\left(\mathrm{PO}_{4}{ }^{3-}-\mathrm{P}\right)$ concentration during the growth period of the Barley. The effluent $\mathrm{PO}_{4}{ }^{3-}-\mathrm{P}$ concentration also independent on water time duration, it was decreased with increasing time duration.

Table 8: Changes in effluent Phosphate - phosphorus $\left(\mathrm{PO}_{4}{ }^{3-}-\mathrm{P}\right)$ concentration for water time duration (3days).

\begin{tabular}{|c|c|c|c|c|c|c|c|c|c|c|c|}
\hline \multirow{2}{*}{$\begin{array}{c}\text { Seed } \\
\text { quantity } \\
\left(\mathrm{kg} / \mathrm{m}^{2}\right)\end{array}$} & \multicolumn{10}{|c|}{ Phosphate - phosphorus $\left(\mathrm{PO}_{4}{ }^{3-}-\mathrm{P}\right) \mathrm{mg} / \mathrm{L}$} & \multirow{2}{*}{$\begin{array}{c}\text { Average } \\
\text { decreased } \\
\mathrm{mg} / \mathrm{L}\end{array}$} \\
\hline & $\mathrm{A}_{1}$ & $\mathrm{~B}_{1}$ & $\mathrm{~A}_{1}$ & $\mathrm{~B}_{1}$ & $\mathrm{~A}_{1}$ & $\mathrm{~B}_{1}$ & $\mathrm{~A}_{1}$ & $\mathrm{~B}_{1}$ & $\mathrm{~A}_{1}$ & $\mathrm{~B}_{1}$ & \\
\hline 1.5 & 2.11 & 1.54 & 1.43 & 0.57 & 1.34 & 0.48 & 1.65 & 0.46 & 2.22 & 0.51 & 1.038 \\
\hline 2.5 & 2.11 & 1.47 & 1.43 & 0.46 & 1.34 & 0.38 & 1.65 & 0.37 & 2.22 & 0.35 & 1.144 \\
\hline
\end{tabular}

Table 9: Changes in effluent Phosphate - phosphorus $\left(\mathrm{PO}_{4}{ }^{3-}-\mathrm{P}\right)$ concentration for water time duration (5days).

\begin{tabular}{|c|c|c|c|c|c|c|c|}
\hline \multirow{2}{*}{$\begin{array}{c}\text { Seed quantity } \\
\left(\mathrm{kg} / \mathrm{m}^{2}\right)\end{array}$} & \multicolumn{6}{|c|}{ Phosphate - phosphorus $\left(\mathrm{PO}_{2}{ }^{3-}-\mathrm{P}\right) \mathrm{mg} / \mathrm{L}$} & $\begin{array}{c}\text { Average } \\
\text { Decreased } \\
\mathrm{mg} / \mathrm{L}\end{array}$ \\
\hline 1.5 & 2.11 & 1.34 & 1.16 & 0.35 & 1.69 & 0.28 & 1.06 \\
\hline 2.5 & 2.11 & 0.82 & 1.16 & 0.22 & 1.69 & 0.16 & 1.25 \\
\hline
\end{tabular}

Both of the Table 8 and 9 indicated the Phosphate - phosphorus $\left(\mathrm{PO}_{4}{ }^{3-}\right.$ P) concentration in influent and effluent for two times duration (3-5 days) static in hydroponic system. From the results it could be absorved that $\left(\mathrm{PO}_{4}{ }^{3-}-\mathrm{P}\right)$ concentration decreased by average 1.038 and $1.144 \mathrm{mg} / \mathrm{Lfor}$ $1.5 \mathrm{~kg} / \mathrm{m}^{2}$ and $2.5 \mathrm{~kg} / \mathrm{m}^{2}$ seed quantity with time duration of three days, while 1.06 and $1.25 \mathrm{mg} / \mathrm{Lfor} 1.5 \mathrm{~kg} / \mathrm{m}^{2}$ and $2.5 \mathrm{~kg} / \mathrm{m}^{2}$ seed quantity with 5 days. 


\subsubsection{Potassium:}

Table 10 shows the changes in effluent potassium oxide $\left(\mathrm{K}_{2} \mathrm{O}\right)$ concentration during the growth period from day of 8 to day of 23, the $\mathrm{K}_{2} \mathrm{O}$ concentration decreased with increasing time duration.

Table 10: Changes in effluent potassium oxide $\left(\mathrm{K}_{2} \mathrm{O}\right)$ concentration for water time duration (3days)

\begin{tabular}{|c|c|c|c|c|c|c|c|c|c|c|c|}
\hline \multirow{2}{*}{$\begin{array}{c}\text { Seed } \\
\text { quantity } \\
\left(\mathrm{kg} / \mathrm{m}^{2}\right)\end{array}$} & \multicolumn{10}{|c|}{ potassium oxide $\left(\mathrm{K}_{2} \mathrm{O}\right) \mathrm{mg} / \mathrm{L}$} & \multirow{2}{*}{$\begin{array}{c}\text { Average } \\
\text { decreased } \\
\mathrm{mg} / \mathrm{L}\end{array}$} \\
\hline & $\mathrm{A}_{1}$ & $\mathrm{~B}_{1}$ & $\mathrm{~A}_{1}$ & $\mathrm{~B}_{1}$ & $\mathrm{~A}_{1}$ & $\mathrm{~B}_{1}$ & $\mathrm{~A}_{1}$ & $\mathrm{~B}_{1}$ & $\mathrm{~A}_{1}$ & $\mathrm{~B}_{1}$ & \\
\hline 1.5 & 90.7 & 89.5 & 83 & 81.6 & 106.9 & 104.2 & 100.5 & 97.7 & 98.8 & 95.7 & 2.24 \\
\hline 2.5 & 90.7 & 89.1 & 83 & 81.1 & 106.9 & 103.7 & 100.5 & 97.2 & 98.8 & 95.2 & 2.72 \\
\hline
\end{tabular}

Table 11: Changes in effluent potassium oxide $\left(\mathrm{K}_{2} \mathrm{O}\right)$ concentration for water time duration (5days)

\begin{tabular}{|c|c|c|c|c|c|c|c|}
\hline \multirow{2}{*}{$\begin{array}{c}\text { Seed quantity } \\
\left(\mathrm{kg} / \mathrm{m}^{2}\right)\end{array}$} & \multicolumn{6}{|c|}{ potassium oxide $\left(\mathrm{K}_{2} \mathrm{O}\right) \mathrm{mg} / \mathrm{L}$} & $\begin{array}{c}\text { Average } \\
\text { Decreased } \\
\mathrm{mg} / \mathrm{L}\end{array}$ \\
\cline { 2 - 8 } & $\mathrm{A}_{2}$ & $\mathrm{~B}_{2}$ & $\mathrm{~A}_{2}$ & $\mathrm{~B}_{2}$ & $\mathrm{~A}_{2}$ & $\mathrm{~B}_{2}$ & \\
\hline 1.5 & 90.7 & 89.1 & 80.4 & 78 & 104.2 & 100.5 & 2.57 \\
\hline 2.5 & 90.7 & 88.5 & 80.4 & 77.4 & 104.2 & 77.4 & 3.27 \\
\hline
\end{tabular}

Concentration of potassium oxide $\left(\mathrm{K}_{2} \mathrm{O}\right)$ in influent and effluent water in the hydroponic system decreased by average 2.24 and $2.72 \mathrm{mg} / \mathrm{L}$ for $1.5 \mathrm{~kg} / \mathrm{m}^{2}$ and $2.5 \mathrm{~kg} / \mathrm{m}^{2}$ seed quantity with time duration of three days, while 2.57 and $3.27 \mathrm{mg} / \mathrm{Lfor} 1.5 \mathrm{~kg} / \mathrm{m}^{2}$ and $2.5 \mathrm{~kg} / \mathrm{m}^{2}$ seed quantity with 5days.

\subsubsection{Pollutions reduction:}

Figures $(2,3,4$ and 5) indicated that the reduction during the planting period which was 23 days. It shows that the reduction percentage of COD, TS, N, P and K increased with the plant growing period every 3 or 5 days, we add a new influent which content high concentration of the previous element but the reduction percentage have been increases. That may be occurring because of increasing the plant nutrient.

Fig.(2) indicated that the pollution reduction increased by plant growth. The highest pollution reduction at day of 23 was $32.33,32.44,57.72$, 
77.02 and $3.13 \%$ can be achieved for the chemical oxygen demand (COD), total solids (TS), Nitrate - Nitrogen $\left(\mathrm{NO}_{3}{ }^{-} \mathrm{-N}\right)$, Phosphate phosphorus $\left(\mathrm{PO}_{4}{ }^{3-}-\mathrm{P}\right)$ and potassium oxide $\left(\mathrm{K}_{2} \mathrm{O}\right)$, respectively

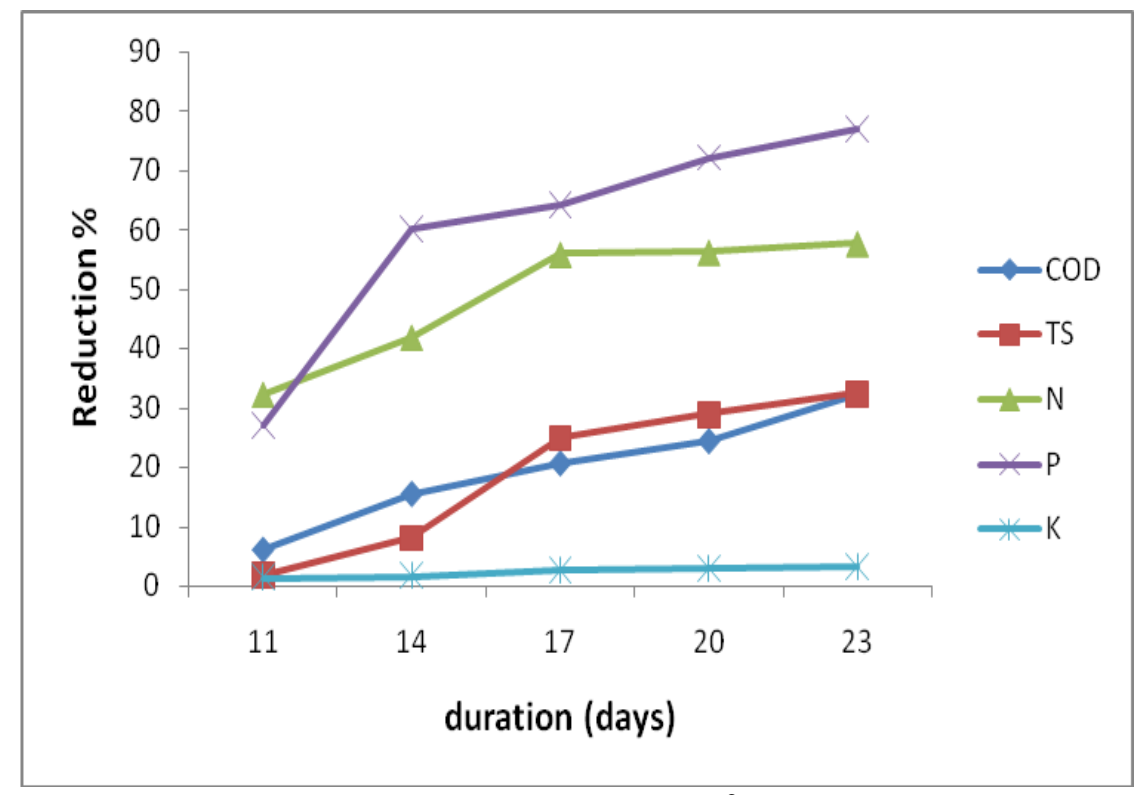

Fig. 2: The pollution reduction for $1.5 \mathrm{~kg} / \mathrm{m}^{2}$ seed quantity and 3days water time duration.

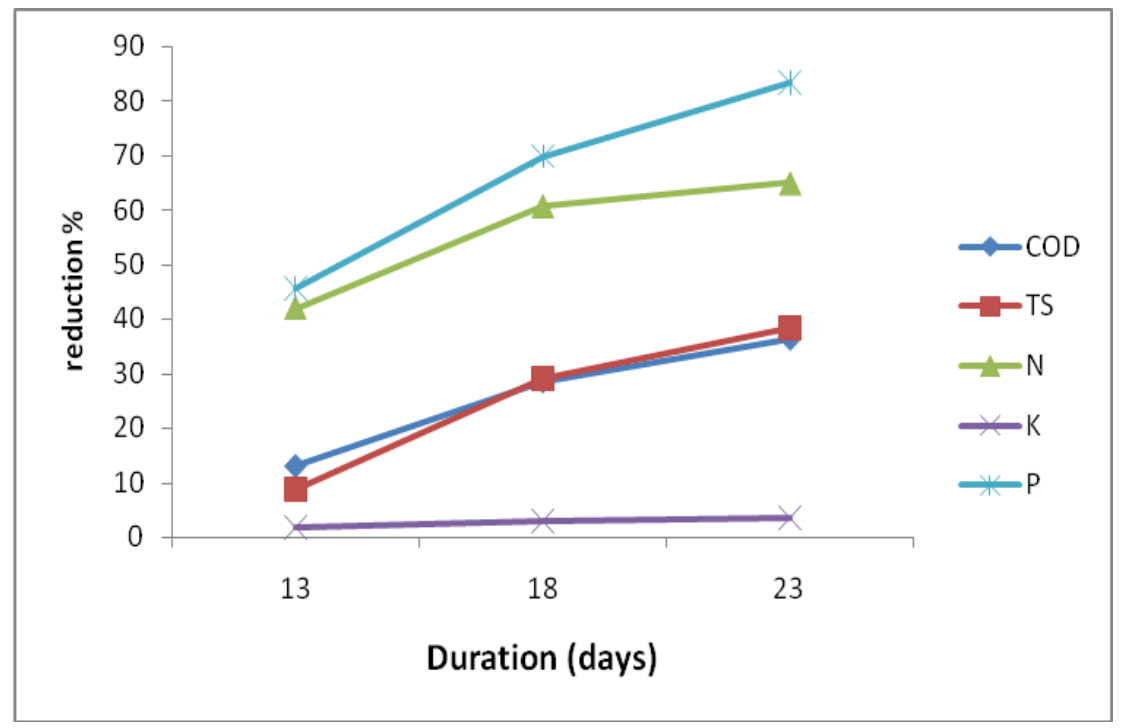

Fig. 3: Fig The pollution reduction for $1.5 \mathrm{~kg} / \mathrm{m}^{2}$ seed quantity and 5days water time duration. 


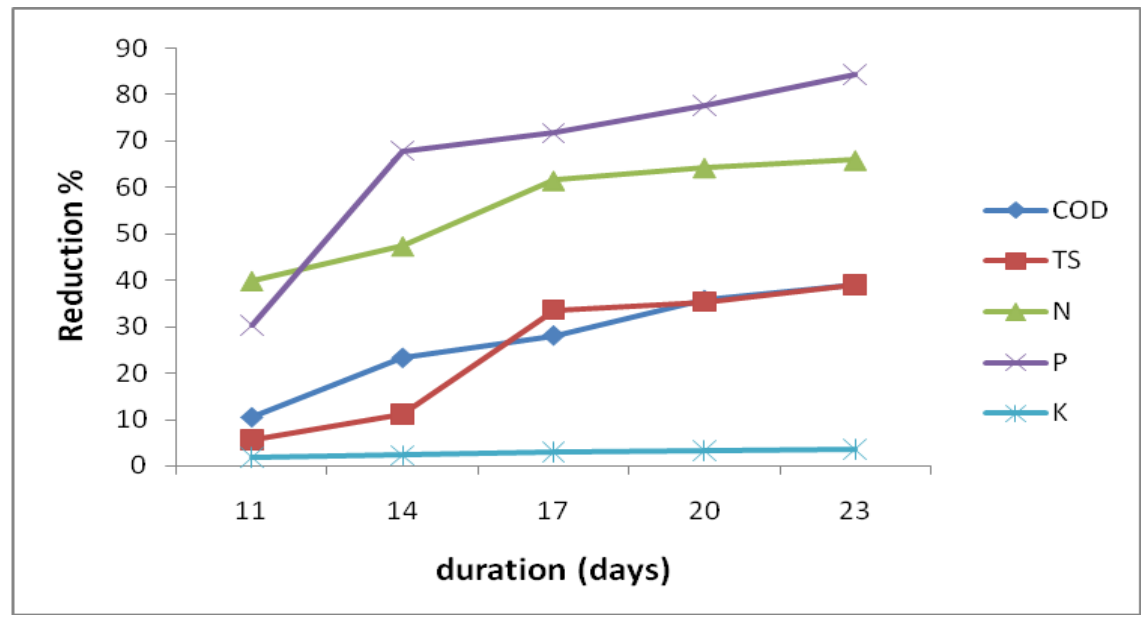

Fig. 4: The pollution reduction for $2.5 \mathrm{~kg} / \mathrm{m}^{2}$ seed quantity and 3days water time duration.

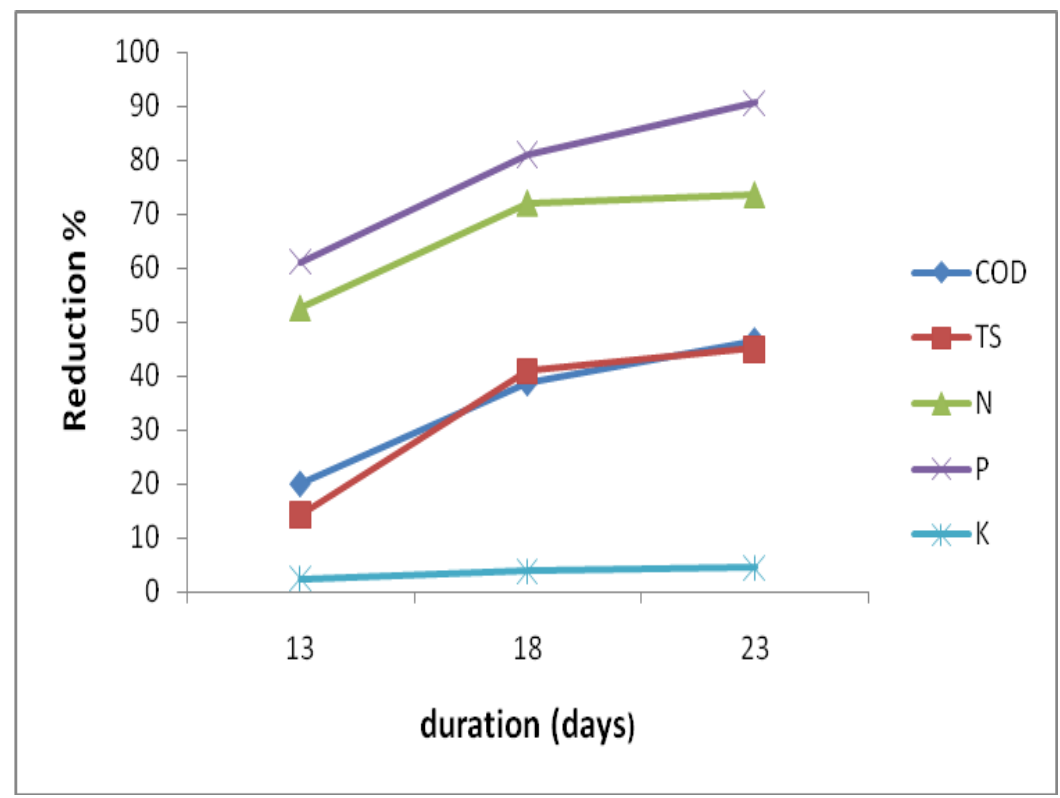

Fig. 5: The pollution reduction for $2.5 \mathrm{~kg} / \mathrm{m}^{2}$ seed quantity and 5 days water time duration.

Fig. (4) Showed that the pollution reduction increased by plant growth. The highest pollution reduction at day 23 was $39.1,39.11,65.9,84.23$ and $3.64 \%$ can be achieved for the chemical oxygen demand (COD), total solids (TS), Nitrate - Nitrogen $\left(\mathrm{NO}_{3}{ }^{-} \mathrm{N}\right)$, Phosphate - phosphorus $\left(\mathrm{PO}_{4}{ }^{3-}-\mathrm{P}\right)$ and potassium oxide $\left(\mathrm{K}_{2} \mathrm{O}\right)$, respectively. 
Fig. (5) showed that the pollution reduction increased by plant growth The highest pollution reduction at day of 23 was $46.51,45.06,73.5$, 90.53 and $4.41 \%$ can be achieved for the chemical oxygen demand (COD), total solids (TS), Nitrate - Nitrogen $\left(\mathrm{NO}_{3}{ }^{-} \mathrm{N}\right)$, Phosphate phosphorus $\left(\mathrm{PO}_{4}{ }^{3-}-\mathrm{P}\right)$ and potassium oxide $\left(\mathrm{K}_{2} \mathrm{O}\right)$, respectively.

From the results can be indicated that the best treatment have the highest reduction was $500 \mathrm{~g}$ seed quantity with 5days water time duration.

\subsection{Plant yield:}

The average crop height increasing by time in the first 10 days all plant grew quickly and fairly uniformly with green colure and good healthy except the last four days the plant appear to be yellow. The plant height for seed quantity $1.5 \mathrm{~kg} / \mathrm{m}^{2}$ were $25.7 \mathrm{~cm}$ and $24.5 \mathrm{~cm}$ for time duration 3 and 5 days and $25.5 \mathrm{~cm}$ and $24 \mathrm{~cm}$ for $2.5 \mathrm{~kg} / \mathrm{m}^{2}$ seed quantity with time duration 3 and 5 days, respectively. And the percentage of dry matter were $10.41 \%$ and $12.9 \%$ for $1.5 \mathrm{~kg} / \mathrm{m}^{2}$ seed quantity with 3 and 5 days time duration and $15.4 \%$ and $18.4 \%$ for $2.5 \mathrm{~kg} / \mathrm{m}^{2}$ seed quantity with 3 and 5 days time duration, respectively. The crop yield average at harvest time for seed quantity $1.5 \mathrm{~kg} / \mathrm{m}^{2}$ was 14.20 and $16.9 \mathrm{~kg} / \mathrm{m}^{2}$ for time duration 3 and 5 days and 15.76 and $17.23 \mathrm{~kg} / \mathrm{m}^{2}$ for $2.5 \mathrm{~kg} / \mathrm{m}^{2}$ seed quantity with time duration 3 and 5 days, respectively.

\section{5-CONCLUSION:}

The study has been assisted to study the possibility of produce Barley crop by using influent waste water from fish pond as a nutrient for Barley. An integrated aquaponic system was installed. A treatment combination of seeding quantity $(1.5 \mathrm{~kg}$ and $2.5 \mathrm{~kg})$ and time duration (3 and 5 days). The treatment $500 \mathrm{~g}$ seed quantity with 5 days for water time duration gave the best result for crop yield $\left(17.23 \mathrm{~kg} / \mathrm{m}^{2}\right)$. The pollution reduction range from $20-46.51 \%, 12.28-45.06 \%, 52.69-73.5 \%, 61.13-$ $90.53 \%$ and $2.43-4.41 \%$ can be achieved for the chemical oxygen demand (COD), total solids (TS), Nitrate - Nitrogen $\left(\mathrm{NO}_{3}{ }^{-} \mathrm{-N}\right)$, Phosphate - phosphorus $\left(\mathrm{PO}_{4}{ }^{3-}-\mathrm{P}\right)$ and potassium oxide $\left(\mathrm{K}_{2} \mathrm{O}\right)$, respectively.

\section{6- RECOMMENDATION:}

It was recommended to use the integrated aquaponic system to produce vegetative Barley as a forage crop and fish meet in 23days by using 
$2.5 \mathrm{~kg}$ seed quantity with 5 days water standing duration, the finley yield of the forage crop found to be $17.23 \mathrm{~kg} / \mathrm{m}^{2}$.

\section{REFERANCE}

A.O.A.C (1990) Official methods of analysis association of official analytical chemist's end. VA, USA, P.634.

Adler, P. R.; S. T. Summerfelt; D. M. Glenn and F. Takeda (2003). Mechanistic approach to phytoremediation of water. Ecol. Eng. 20, 251-264.

Bhatnagar,A., P. Devi (2013). Water quality guidelines for the management of pond fish culture International Journal of Environmental Sciences. Volume 3, No. 6, 2013. ISSN 0976 4402.

DeLong, D. P., T. M. Losordo and J. E. Rakocy (2009). Tank Culture of Tilapia. Southern Regional Aquaculture Center SRAC Publication No. 282. 1-8

FAO (2013). Statistical year book 2013 World Food and Agriculture. Food and Agriculture Organization of the United Nations. Rome. P180

Gegner, L. (2006). Aquaculture Enterprises: Considerations and Strategies. NCAT Agriculture Specialist CNCAT, 2006: 1-16. www.attra.ncat.org/attra-pub/PDF/aquaculture.pdf

Ghaly, A. E. and H. A. Farag (2007). Phytoremediation of an aerobic digester effluent for water purification and production of animal feed. American Journal of Agricultural and Biological Science. 2(1): 1-14.

Murray, F.; J. Bostock and D. Fletcher (2014). RAS Technologies and their Commercial Application (Final Report). Prepared for Highlands and Islands Enterprise. 1-65

Sorenson, R. and D. Relf (2009). Home Hydroponics. College of Agriculture and Life Sciences. Virginia Polytechnic Institute and State University. Publication 426-084. 
Snow, A.M. (2007). Purification of aquaculture waste water and production of fish feed using agriculture and plants. Thesis. Dalhousie University. 1-339

ابو حديد أ. ف. ، أ. أ. البحيري، م. ن. بكير ، س. ح. احمد، نيفين ا. متولي و أ. ت. المرسي

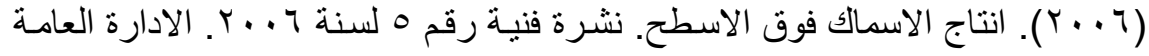

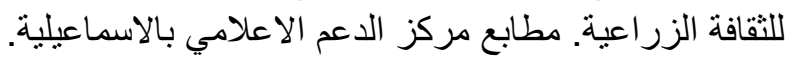

\section{الملخص العربي}

\section{نظام متكامل لمعالجه مياه الاستزراع السمكي لانتاج الشعير

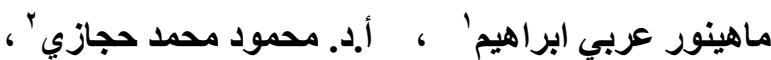

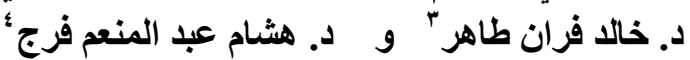

تم انثاء نظام متكامل لمعالجة مياه الاستزراع السمكى لانتاج اسماك ومحاصيل علف , ثم در اسة تأثير كمية الحبوب مع مدة بقاء الماء علي انتاجية محصول العلف ونسبة التنقية. اظهرت النتائج انه يمكن الحصول على محصول علف فى بr يوم من بداية الانبات وحتى الحصاد.

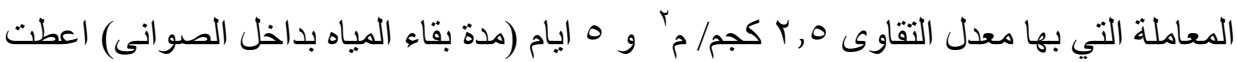

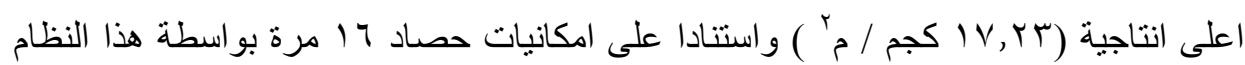

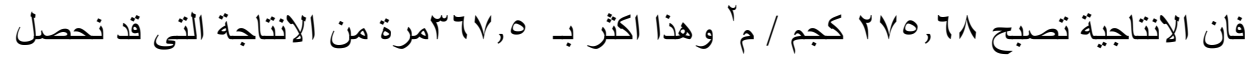

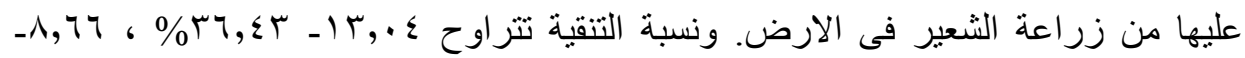
TS ، COD ع و ، N ،

ا ـ طالبه دراسات عليا - مساعد باحث بمعهد بحوث الهندسة الزراعيه ـ مركز البحوث الزراعية.

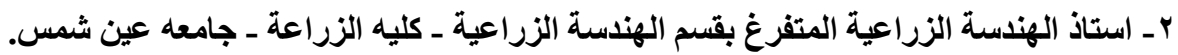

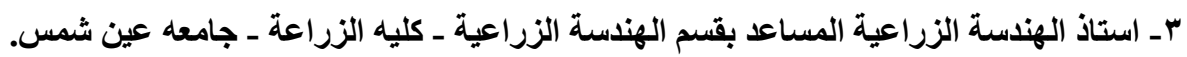
ع - باحث اول بمعهد بحوث الهندسة الزراعيه ـ مركز البحوث الزراعية الزية. 